\title{
BRITTLE FRACTURE RESISTANCE OF HAZ METAL IN ARC-WELDED JOINTS OF HIGH-STRENGTH STEELS WITH CARBON CONTENT OF 0.55-0.65 \%
}

\author{
A.A. GAJVORONSKY, V.D. POZNYAKOV, L.I. MARKASHOVA, E.N. BERDNIKOVA and V.Ya. YASHCHUK \\ E.O. Paton Electric Welding Institute, NASU \\ 11 Kazimir Malevich Str., 03680, Kiev, Ukraine. E-mail: office@paton.kiev.ua
}

\begin{abstract}
Modeling methods were used to study the influence of structural-phase composition and diffusible hydrogen on brittle fracture resistance of HAZ metal of high-strength steel with carbon content of $0.55-0.65 \%$. It is shown that to achieve comparatively high resistance of the joints to crack propagation, it is necessary to ensure formation in the HAZ metal of bainitic-martensitic structure, in which upper bainite is absent, and martensite volume fraction does not exceed lower bainite fraction. At saturation of HAZ metal with hydrogen, which diffuses from deposited metal during arc welding or surfacing, its brittle fracture susceptibility increases markedly. To reduce metal embrittlement, it is necessary to apply special welding techniques, at which hydrogen saturation is minimum (less than $0.2 \mathrm{ml} / 100 \mathrm{~g}$ ), or special technological methods, allowing improvement of ductile properties of HAZ metal. 14 Ref., 1 Table, 10 Figures.
\end{abstract}

Keywords : high-strength carbon steel, arc welding, HAZ, structure, diffusible hydrogen, brittle fracture, fracture surface

One of the main factors, determining the level of brittle fracture resistance of welded joints of highstrength steels, is structural state of steel and HAZ metal, formed during the thermodeformational welding cycle (TDWC). This condition greatly depends on carbon content in steel and cooling rate of welded joint HAZ metal [1, 2]. It is also known that diffusible hydrogen has a significant impact on metal embrittlement. Accumulating in structural discontinuities, it promotes increase of local stresses and, as a consequence, brittle fracture resistance of the metal decreases. Hydrogen influence becomes stronger with increase of carbon content that leads to a more abrupt lowering of plastic properties of metal, resulting in more intensive crack initiation and propagation [3-5].

In arc welding and surfacing of high-strength steels, carbon content in which is higher than $0.50 \%$, a hardened bainitic-martensitic structure with higher dislocation density forms in HAZ overheated zone. Ultimate rupture strength of such metal is more than $1060 \mathrm{MPa}$, and relative elongation is not higher than $9.3 \%[6,7]$. It can be assumed that in welding highstrength carbon steels even slight local concentrations of hydrogen will lead to significant changes in brittle fracture resistance of HAZ metal.

Objective of this work was determination of the influence of structural-phase composition and diffusible hydrogen on brittle fracture resistance of HAZ metal of welded joints in high-strength carbon steels.
Used as material for investigations were highstrength carbon steels of the following compositions, wt.\%: wheel steel of grade 2 (DSTU GOST 10791) $0.58 \mathrm{C}$; $0.44 \mathrm{Si} ; 0.77 \mathrm{Mn} ; 0.10 \mathrm{Ni} ; 0.05 \mathrm{Cr} ; 0.012 \mathrm{~S}$; $0.11 \mathrm{P}$; and structural carbon steel 65G (GOST $1050)-0.65 \mathrm{C} ; 0.19 \mathrm{Si} ; 0.91 \mathrm{Mn} ; 0.18 \mathrm{Ni} ; 0.16 \mathrm{Cr}$; $0.017 \mathrm{~S} ; 0.010 \mathrm{P}$.

Methods of investigation. Assessment of brittle fracture resistance of the metal was performed in keeping with standard method of three-point bending [8-10]. Samples of studied steels of $100 \times 20 \times 10 \mathrm{~mm}$ size with $7 \mathrm{~mm}$ deep notch in the center were used. Before testing, $3 \mathrm{~mm}$ long fatigue crack was grown in the notch tip by loading by cyclic bending (cycle stress of $120 \mathrm{MPa}$, frequency of $35 \mathrm{~Hz}$ ). Sample loading rate at static bending was equal to $1 \mathrm{~mm} / \mathrm{min}$. Critical stress intensity factor $K_{1 C}$ was taken as the criterion of assessment of brittle fracture resistance of the metal.

HAZ metal resistance to brittle fracture was assessed using a sample of similar dimensions, treated by TDWC, followed by growing a fatigue crack in it. For TDWC simulation, rigidly-restrained samples were heated by passing current up to $1250^{\circ} \mathrm{C}$ (heating rate of $150{ }^{\circ} \mathrm{C} / \mathrm{s}$ ), and then cooled by specified cycle. Sample cooling rate in the temperature range of 600 $500{ }^{\circ} \mathrm{C}$ was selected from the conditions of formation of characteristic structures in welded joint HAZ metal. For wheel steel of grade 2 cooling rate was $w_{6 / 5}=6^{\circ} \mathrm{C} / \mathrm{s}$, when a structure of bainite forms in HAZ 
metal overheated zone, $13.5{ }^{\circ} \mathrm{C} / \mathrm{s}$ for bainitic-martensitic structure and $20{ }^{\circ} \mathrm{C} / \mathrm{s}$ for martensitic-bainitic structure. Investigations on steel $65 \mathrm{G}$ were performed at $w_{6 / 5}=6$ and $13.5^{\circ} \mathrm{C} / \mathrm{s}$, when bainitic-martensitic and martensitic structures form, respectively.

Saturation of samples with a fatigue crack by diffusible hydrogen $[\mathrm{H}]_{\text {dif }}$ was performed electrolytically (current density of $10 \mathrm{~A} / \mathrm{cm}^{2}$ ) just before their static loading. Electrolytic solution of sulphuric acid $\mathrm{H}_{2} \mathrm{SO}_{4}$ in distilled water with addition of sodium thiosulphate $\mathrm{Na}_{2} \mathrm{~S}_{2} \mathrm{O}_{2}$ in the proportion of $0.05 \mathrm{~g}$ per $1 \mathrm{l}$ was used for this purpose. $[\mathrm{H}]_{\text {dif }}$ quantity was varied in the range of $0.2-1.5 \mathrm{ml}$ per $100 \mathrm{~g}$ of metal by changing the time of samples soaking in electrolytic solution. This was performed in keeping with the data of [11], which showed that diffusible hydrogen content in the HAZ can reach $1.5 \mathrm{ml} / 100 \mathrm{~g}$ at its initial amount in the deposited metal of up to $10 \mathrm{ml} / 100 \mathrm{~g}$.

HAZ metal structure was studied by the methods of optical metallography. Sample fractures after testing were studied by the methods of scanning electron microscopy in Philips scanning electron microscope SEM-515, fitted with energy-dispersive spectrometer of LINK system.

Investigation results and their discussion. At the initial stage of investigations, facture mechanics approaches and criteria were used to determine the influence of steel structural state on critical stress intensity factor. Figure 1 gives generalized results of testing performed at the temperature of $20^{\circ} \mathrm{C}$. As is seen from the given data, brittle fracture resistance of steel in the initial state significantly depends on its structure and carbon content. For steel $65 \mathrm{G}$ critical SIF is approximately 1.4 times higher than for wheel steel of grade 2 (72 and $52 \mathrm{MPa} \sqrt{\mathrm{m}}$, respectively). This difference is, most probably, associated with the features of metal phase composition and structure parameters. Metallographic studies showed that structure of grade 2 wheel steel is presented by pearlite-ferrite mixture (Figure 2,a) with grain size between 16 and $32 \mu \mathrm{m}$. Microhardness of structural components is in the range of HV0.1-1990-2450 MPa, and total integral hardness of metal is equal to HV10$2300 \mathrm{MPa}$. Ferrite fringes 5-10 $\mu \mathrm{m}$ wide are located along grain boundaries. Structure of as-delivered steel $65 \mathrm{G}$ is represented predominantly by bainite (Figure 2, $b$ ), grain size is $16-24 \mu \mathrm{m}$, microhardness of structural components is $2570-2730 \mathrm{MPa}$, and integral hardness of metal is $2760 \mathrm{MPa}$.

One can see that high-carbon steel with bainitic structure has higher resistance to brittle fracture at three-point bending than steel with pearlitic-ferritic structure. It should be also noted that similar results were obtained by authors of [12] at testing high-carbon steel under cyclic loading.

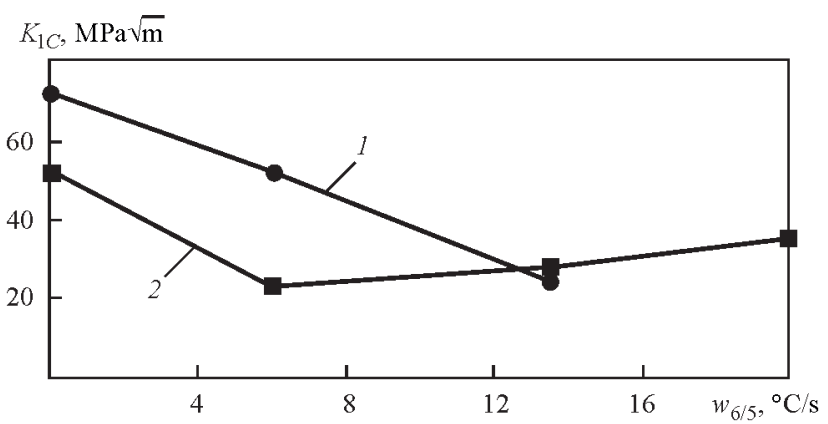

Figure 1. Brittle fracture resistance of HAZ metal of steel $65 \mathrm{G}$ (1) and wheel steel of grade 2 (2)

Further studies showed that structural changes in the metal, induced by the TDWC, also have a significant impact on its brittle fracture resistance. Carbon content in steel plays a determinant role here. Figure 3 gives the diagrams of supercooled austenite transformation in HAZ metal of studied steels, and Figure 4 shows the characteristic microstructure of metal [13, 14]. Let us analyze these data in comparison with changes of $K_{1 C}$ value.

Under the conditions of welding, when $w_{6 / 5}=6^{\circ} \mathrm{C} / \mathrm{s}, \mathrm{HAZ}$ metal of grade 2 steel forms a structure of upper bainite (Figure 3,a) with coarse grain (63-94 $\mu \mathrm{m})$ and microhardness of 2640-3090 MPa (Figure $4, a$ ). Integral hardness of metal with such a structure is equal to $3140 \mathrm{MPa}$. It is known that upper bainite, formed by diffusion mechanism, has lower ductility, unlike other metal structures [1]. Therefore, brittle fracture resistance of such metal drops markedly. This is confirmed by the results of testing samples with a crack for three-point bending. Testing showed

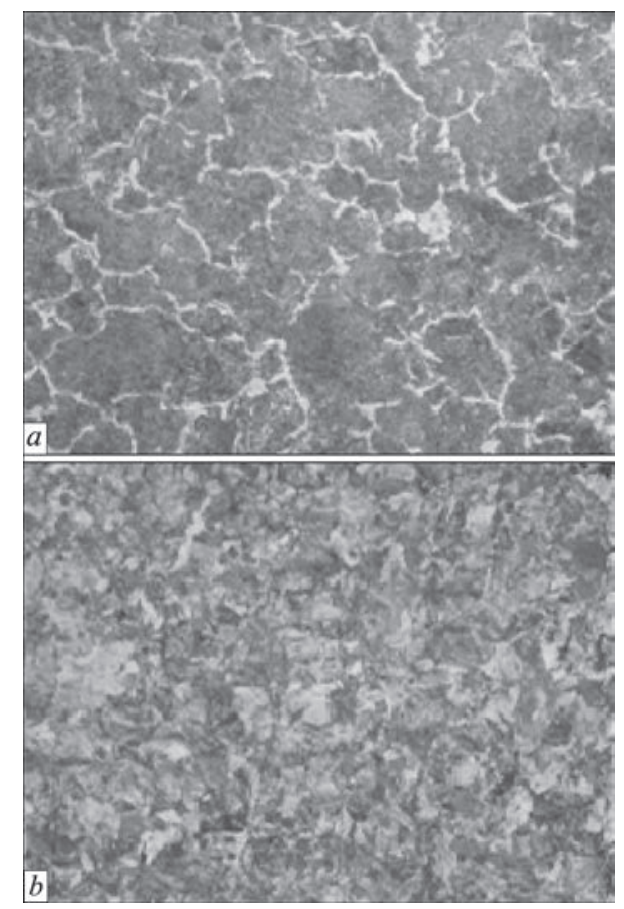

Figure 2. Microstructure of as-delivered grade 2 wheel steel $(a-$ $\times 500)$ and $65 \mathrm{G}$ steel $(b-\times 200)$ 

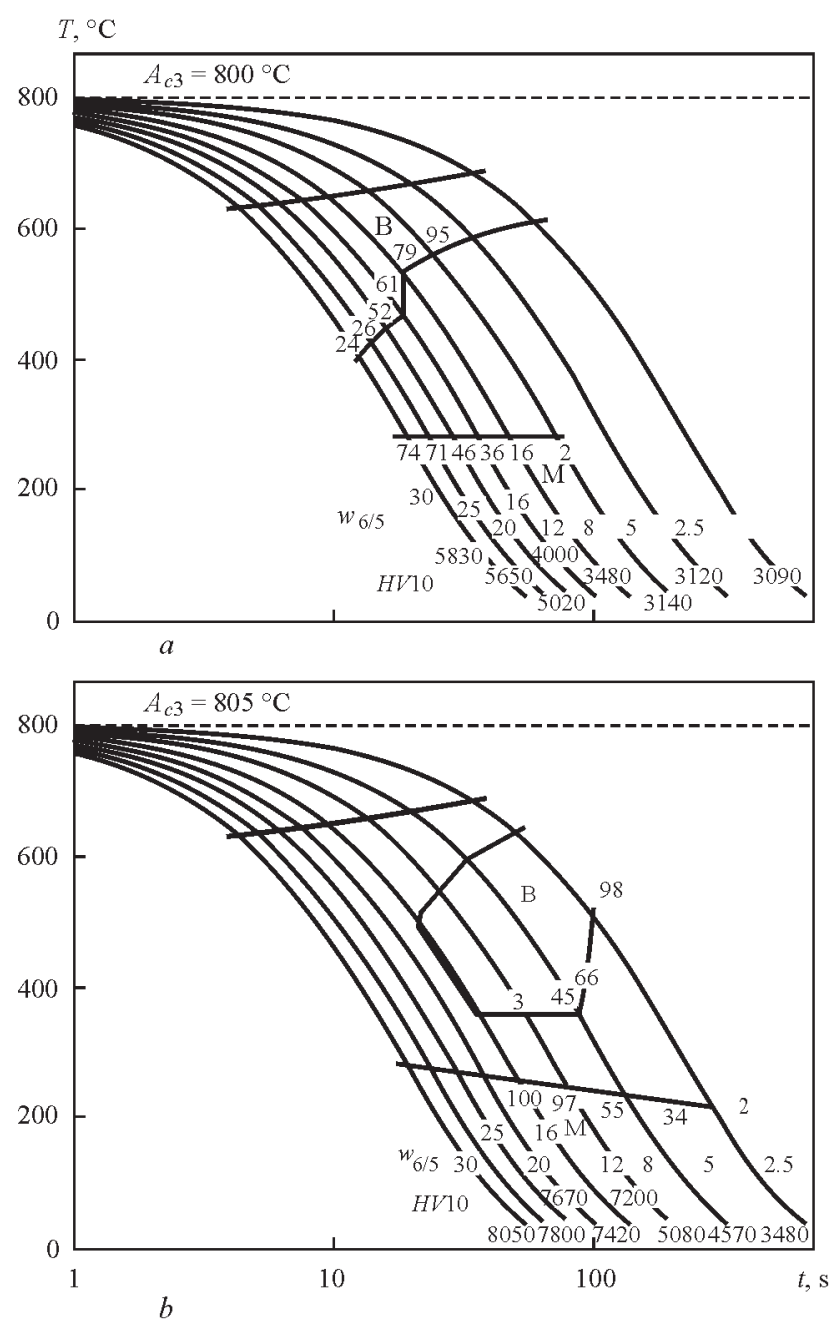

Figure 3. Supercooled austenite transformation diagram in HAZ metal of grade 2 wheel steel $(a)$ and $65 \mathrm{G}$ steel $(b)$ in arc welding $\left(T_{\max }=1250^{\circ} \mathrm{C}, t_{\mathrm{h}}=6 \mathrm{~s}\right)[13,14]$

that compared to as-delivered steel $K_{1 C}$ value for HAZ metal decreases 2.3 times (from 52 to $23 \mathrm{MPa} \sqrt{\mathrm{m}}$ see Figure 1, curve 2).

At $w_{6 / 5}=13.5^{\circ} \mathrm{C} / \mathrm{s}$, HAZ metal of grade 2 wheel steel forms a bainitic-martensitic structure with microhardness of 3340-4320 MPa, in which lower bain- ite prevails $(80 \%)$ (Figure $4, b)$. Such changes in the structure, compared to metal with upper bainite structure, promoted its brittle fracture resistance rising by $22 \%$ (up to $28 \mathrm{MPa} \sqrt{\mathrm{m}}$ ).

At $20{ }^{\circ} \mathrm{C} / \mathrm{s}$ a structure with approximately equal quantity of martensite and lower bainite (46 and $54 \%$, respectively) forms in overheated zone of HAZ metal. Microhardness of metal structural components rises up to $3780-4560 \mathrm{MPa}$ (integral hardness of $3920 \mathrm{MPa}$ ), and grain size decreases to $32.0-47.5 \mu \mathrm{m}$ (Figure $4, c$ ). With such a structure, $K_{1 C}$ value is the largest, and is equal to $35 \mathrm{MPa} \sqrt{\mathrm{m}}$. But even under such conditions brittle fracture resistance of HAZ metal is approximately 1.5 times lower, compared to initial condition of wheel steel.

Unlike grade 2 wheel steel, in $65 \mathrm{G}$ steel $(0.65 \% \mathrm{C})$ bainitic-martensitic structure forms at $w_{6 / 5}=6{ }^{\circ} \mathrm{C} / \mathrm{s}$, which contains $70 \%$ lower bainite and $30 \%$ martensite (Figure 3, b). Microhardness of lower bainite is $3220-3800 \mathrm{MPa}$, and that of martensite is 5600 $6130 \mathrm{MPa}$, grain size varies from 63 to $94 \mu \mathrm{m}$ (Figure $5, a$ ). As shown by mechanical testing, $K_{1 C}$ value of HAZ metal with bainitic-martensitic structure decreases by $28 \%$ (from 72 to $52 \mathrm{MPa} \sqrt{\mathrm{m}}$ - see Figure 1 , curve 1 ) relative to steel initial state.

At increase of cooling rate to $13.5^{\circ} \mathrm{C} / \mathrm{s}$, the metal mainly forms a martensitic structure $(98 \%)$ with more than $6130 \mathrm{MPa}$ microhardness (Figures 5, b). At this cooling rate, lower bainite (2\%) is locally distributed along the grain boundaries. Grain size here did not significantly change. At formation of predominantly martensitic structure $\left(w_{6 / 5}=13.5^{\circ} \mathrm{C} / \mathrm{s}\right) K_{1 C}$ value drops markedly to $23 \mathrm{MPa} \sqrt{\mathrm{m}}$. Compared to initial state of steel, brittle fracture resistance of HAZ metal at this cooling rate is lower by approximately 3.1 times.

Comparing the given test results, we can state that in order to improve brittle fracture resistance of HAZ metal in high-strength steel at carbon content of
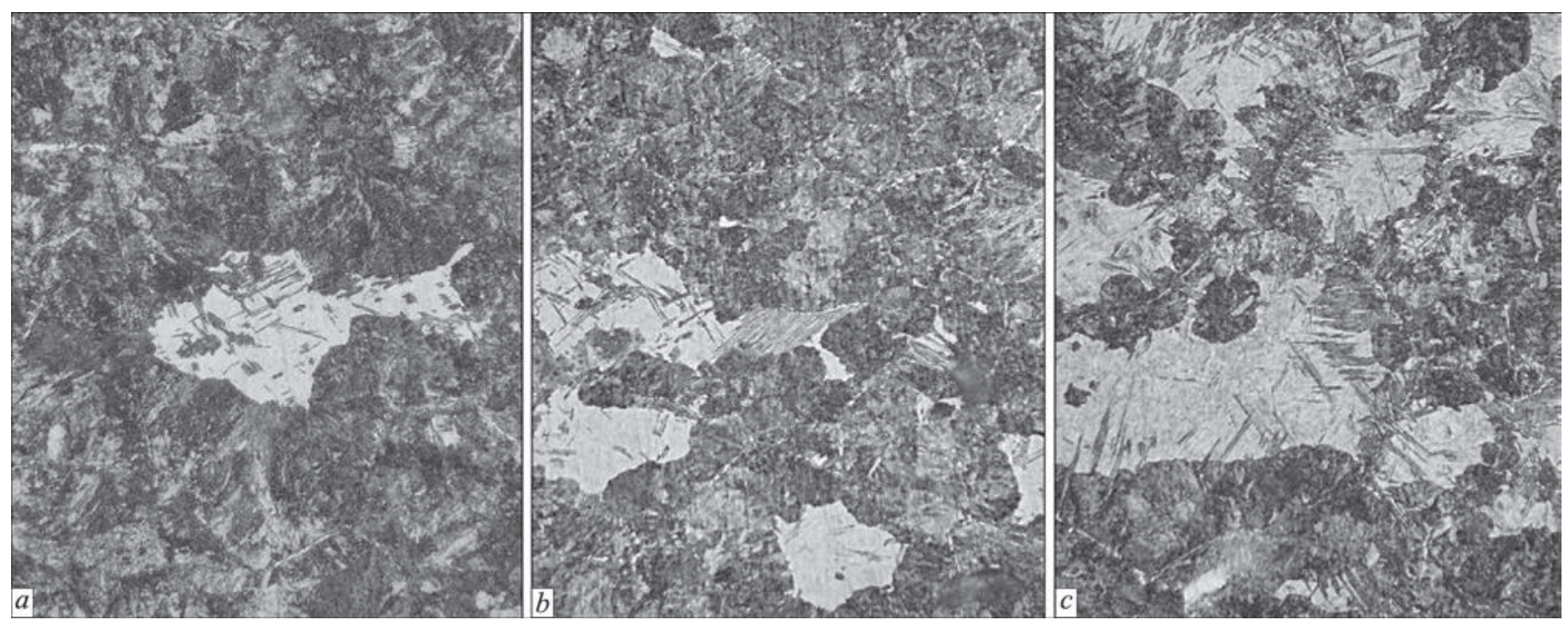

Figure 4. Microstructure of metal $(\times 500)$ in HAZ overheated zone of grade 2 wheel steel: $a-w_{6 / 5}=6 ; b-13.5 ; c-20{ }^{\circ} \mathrm{C} / \mathrm{s}$ 


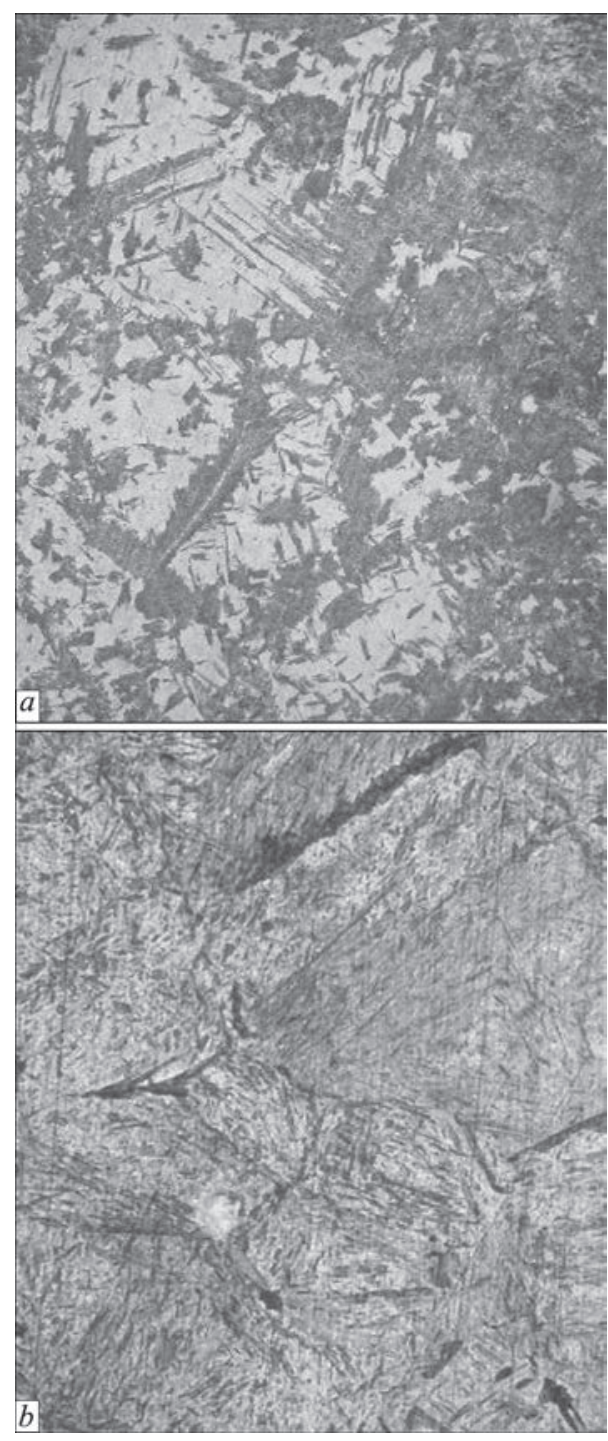

Figure 5. Microstructure $(\times 500)$ of metal in HAZ overheated zone of $65 \mathrm{G}$ steel: $a-w_{6 / 5}=6 ; b-13.5^{\circ} \mathrm{C} / \mathrm{s}$

$0.55-0.65 \%$, it is necessary to provide the conditions, at which a structure, consisting of lower bainite and martensite, will form in it. Volume fraction of martensite should not be higher than $50 \%$. At formation of prevailing structure of upper bainite or martensite in the HAZ, brittle fracture susceptibility of metal rises markedly.

Diffusible hydrogen has a significant impact on brittle fracture resistance of high-carbon steel. At hydrogen saturation of samples of as-delivered steels, $K_{1 C}$ value decreases (Figure 6). Degree of $K_{1 C}$ value lowering depends on carbon content in steel. For grade 2 wheel steel with carbon content of $0.58 \%$, presence of hydrogen in the metal on the level of $0.2 \mathrm{ml} / 100$ g leads to $K_{1 C}$ lowering by $23 \%$ (from 52 to $40 \mathrm{MPa} \sqrt{\mathrm{m}}$ - see curve 2). At increase of hydrogen concentration up to $1.5 \mathrm{ml} / 100 \mathrm{~g}$, SIF drops to $30 \mathrm{MPa} \sqrt{\mathrm{m}}$. Thus, wheel steel resistance to crack propagation decreases approximately 1.7 times in the presence of diffusible hydrogen in the metal.
$K_{1 C}, \mathrm{MPa} \sqrt{\mathrm{m}}$

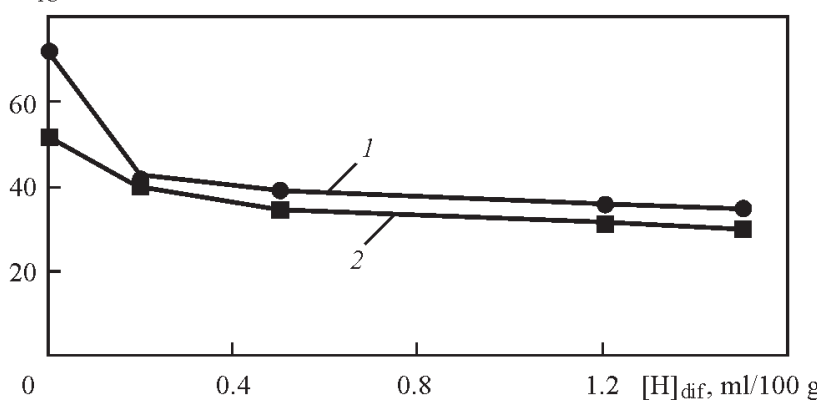

Figure 6. Hydrogen influence on brittle fracture resistance of $65 \mathrm{G}$ steel (1) and grade 2 wheel steel (2)

A more abrupt embrittlement in the presence of hydrogen proceeds in steel, in which hydrogen content is equal to $0.65 \%$. At minimum saturation of steel $65 \mathrm{G}$ with hydrogen, $K_{1 C}$ value decreases by $42 \%$ (from 72 to $42 \mathrm{MPa} \sqrt{\mathrm{m}}$ - see curve 1 in Figure 6), and at its maximum content - by 2.1 times (up to $35 \mathrm{MPa} \sqrt{\mathrm{m}}$ ).

In the presence of diffusible hydrogen in HAZ metal of studied steels its brittle fracture resistance also decreases (Figure 7). Level of this decrease depends on carbon content, which determines the degree of metal hardening under TDWC impact. More marked changes of properties are characteristic for HAZ metal of $65 \mathrm{G}$ steel. Hydrogen presence in it on the level of $0.2 \mathrm{ml} / 100$ g leads to lowering of $K_{1 C}$ value by 2.4-3.2 times (Figure 7, a). For HAZ metal of wheel steel it is 1.1-1.2 times (Figure 7,b). At subsequent increase of $[\mathrm{H}]_{\text {dif }}$ in the metal up to $1.5 \mathrm{ml} / 100 \mathrm{~g}, K_{1 C}$ value for $\mathrm{HAZ}$ metal of $65 \mathrm{G}$ steel gradually decreases up to 2 times, and by $40 \%$ - for wheel steel of grade
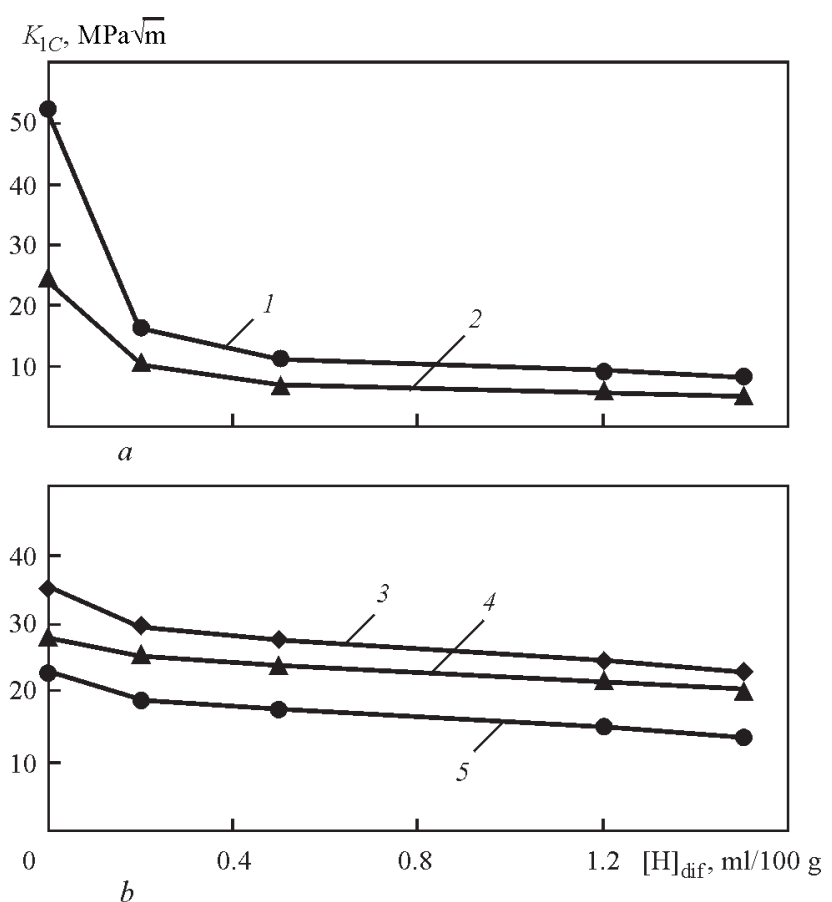

Figure 7. Influence of cooling rate and diffusible hydrogen on brittle fracture resistance of HAZ metal of $65 \mathrm{G}$ steel $(a)$ and grade 2 wheel steel $(b): 1,5-w_{6 / 5}=6 ; 2,4-13.5 ; 3-20^{\circ} \mathrm{C} / \mathrm{s}$ 


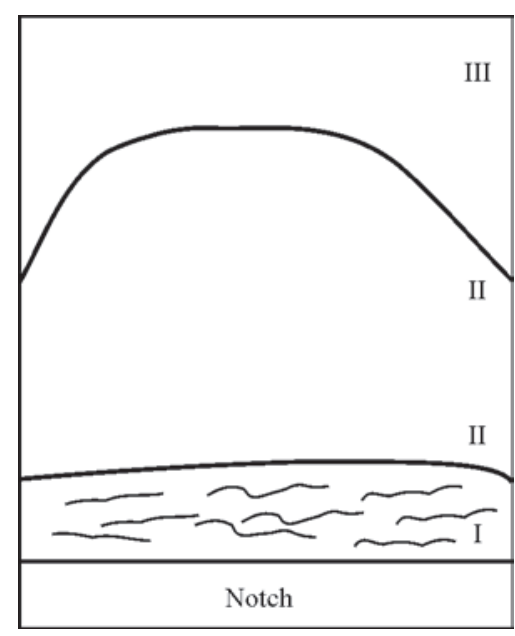

Figure 8. Zones of sample fracture after testing: I - fatigue crack; II - main crack; III - final fracture zone

2. Thus, hydrogen presence in the structure leads to overall lowering of brittle fracture resistance of HAZ metal by 6.5 times for $65 \mathrm{G}$ steel $(52$ and $8 \mathrm{MPa} \sqrt{ } \mathrm{m}$ at $w_{6 / 5}=6^{\circ} \mathrm{C} / \mathrm{s}$ - see Figure 7, $a$, curve 1$)$, and by 1.5 times for wheel steel of grade 2 ( 35 and $23 \mathrm{MPa} \sqrt{\mathrm{m}}$ at $20{ }^{\circ} \mathrm{C} / \mathrm{s}$ - Figure $7, b$, curve 3 ).

As shown by factographic studies, not only $K_{1 C}$ values, but also the mode of sample failure change under the TDWC impact and in the presence of diffusible hydrogen. Characteristic fracture zones (Figure 8) are observed on sample fracture surface: I - zone of initiation and propagation of a fatigue crack, formed as a result of loading by cyclic bending; II — zone of main crack propagation; and final fracture zone III at three-point bending. Characteristic fractures of HAZ metal samples, not saturated by hydrogen, are given in Figure 9.

Fatigue crack initiation in HAZ metal of high-carbon steel, irrespective of its structural state, proceeds in the brittle mode along grain boundaries (Figure 9, a). Fatigue crack propagates also in the brittle mode, but predominantly across the grain body (Figure 9, b). The features of fatigue crack propagation, depending on steel composition and structural state of the metal, are as follows. In HAZ metal of wheel steel with upper bainitic structure $\left(w_{6 / 5}=6{ }^{\circ} \mathrm{C} / \mathrm{s}\right)$ the size of brittle fracture facets is equal to $300-100 \mu \mathrm{m}$, and in metal with bainitic-martensitic structure $\left(13.5^{\circ} \mathrm{C} / \mathrm{s}\right)$ it is 30 $70 \mu \mathrm{m}$. This fracture zone is characterized by presence of secondary cracks along grain boundaries. In grade 2 wheel steel with upper bainite structure these cracks have the size of 50-100 $\mu \mathrm{m}$, and at formation of the structure of lower bainite and martensite in the HAZ their extent decreases to $60 \mu \mathrm{m}$. Similar dimensions of the facets were observed also in fractures of $65 \mathrm{G}$ steel. However, the length of secondary cracks in it increases to $200 \mu \mathrm{m}$.
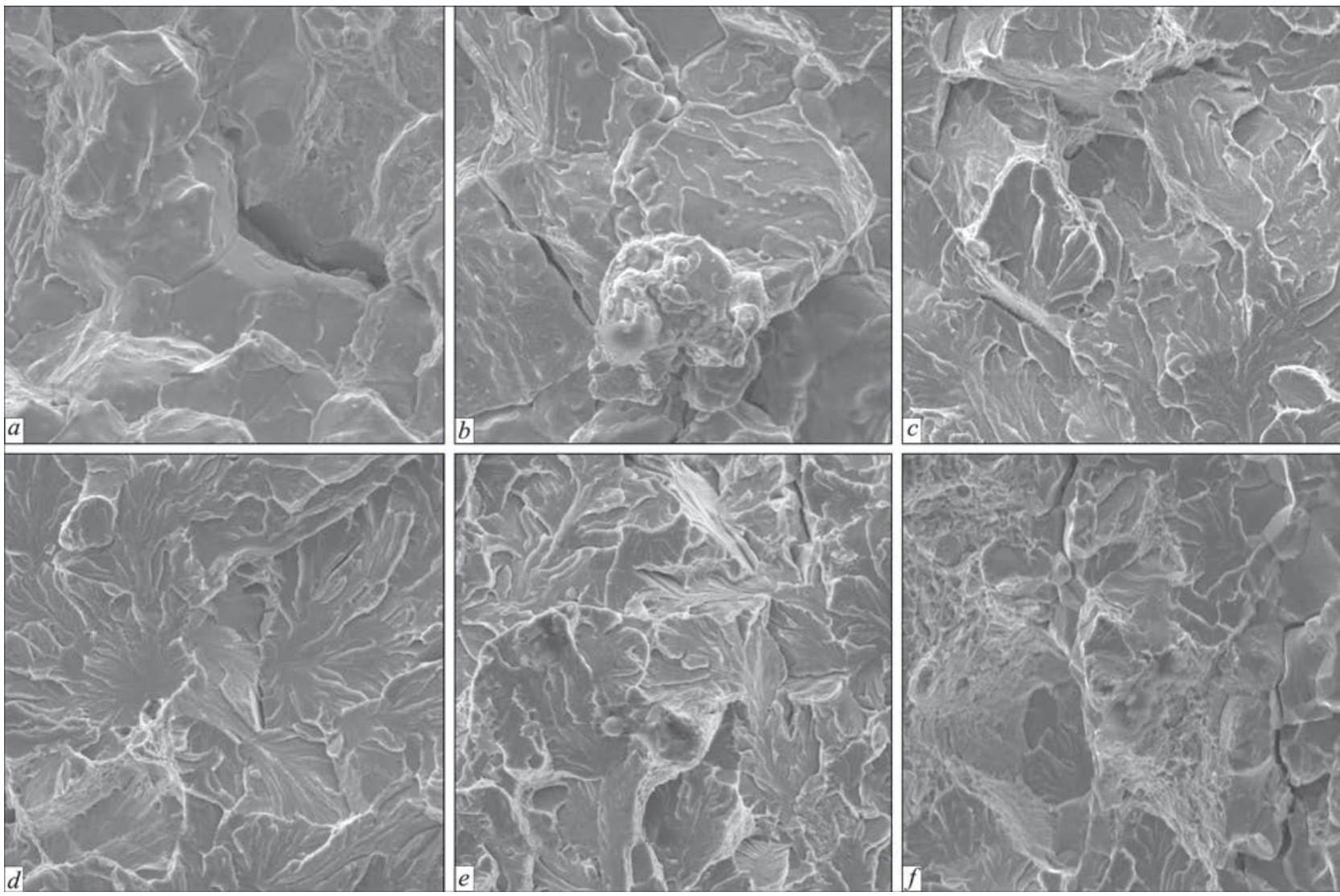

Figure 9. Characteristic fracture $(\times 1010)$ of HAZ metal of grade 2 wheel steel $(a-d)$ and $65 \mathrm{G}$ steel $(e, f)$ without hydrogen: $a, b-$ zone I $\left(a-w_{6 / 5}=6 ; b-13.5\right) ; c, d-$ zone II $(c-6 ; d-13.5) ; e, f-$ zone II $\left(e-6 ; f-13.5^{\circ} \mathrm{C} / \mathrm{s}\right)$ 
HAZ metal brittle fracture mode in main crack propagation zone

\begin{tabular}{|c|c|c|c|c|c|c|c|c|}
\hline \multirow{3}{*}[\mathrm{H}]{$_{\text {dif }}, \mathrm{ml} / 100 \mathrm{~g}$} & \multicolumn{4}{|c|}{ Grade 2 wheel steel } & \multicolumn{4}{c|}{$65 \mathrm{G}$ steel } \\
\cline { 2 - 9 } & \multicolumn{2}{|c|}{$6{ }^{\circ} \mathrm{C} / \mathrm{s}$} & \multicolumn{2}{c|}{$13.5^{\circ} \mathrm{C} / \mathrm{s}$} & \multicolumn{2}{c|}{$6{ }^{\circ} \mathrm{C} / \mathrm{s}$} & \multicolumn{2}{c|}{$13.5^{\circ} \mathrm{C} / \mathrm{s}$} \\
\cline { 2 - 9 } & $\begin{array}{c}\text { Intragranular } \\
\text { fracture, } \\
\% / L_{\mathrm{s}}, \mu \mathrm{m}\end{array}$ & $\begin{array}{c}\text { Intergranular } \\
\text { fracture, } \\
\% / L_{\mathrm{s}}, \mu \mathrm{m}\end{array}$ & $\begin{array}{c}\text { Intragranular } \\
\text { fracture, } \\
\% / L_{\mathrm{s}}, \mu \mathrm{m}\end{array}$ & $\begin{array}{c}\text { Intergranular } \\
\text { fracture, } \\
\% / L_{\mathrm{s}}, \mu \mathrm{m}\end{array}$ & $\begin{array}{c}\text { Intragranular } \\
\text { fracture, } \\
\% / L_{\mathrm{s}}, \mu \mathrm{m}\end{array}$ & $\begin{array}{c}\text { Intergranular } \\
\text { fracture, } \\
\% / L_{\mathrm{s}}, \mu \mathrm{m}\end{array}$ & $\begin{array}{c}\text { Intragranular } \\
\text { fracture, } \\
\% / L_{\mathrm{s}}, \mu \mathrm{m}\end{array}$ & $\begin{array}{c}\text { Intergranular } \\
\text { fracture, } \\
\% / L\end{array}$ \\
\hline 0 & $100 / 40$ & - & $100 / 5$ & - & $95 / 30$ & $5 / 30$ & $80 / 60$ & $20 / 60$ \\
\hline 0.2 & $80 / 100$ & $20 / 100$ & $70 / 40$ & $30 / 40$ & $50 / 150$ & $50 / 150$ & $30 / 220$ & $70 / 220$ \\
\hline 0.5 & $70 / 120$ & $30 / 120$ & $65 / 60$ & $35 / 60$ & $40 / 170$ & $60 / 170$ & $20 / 250$ & $80 / 250$ \\
\hline
\end{tabular}
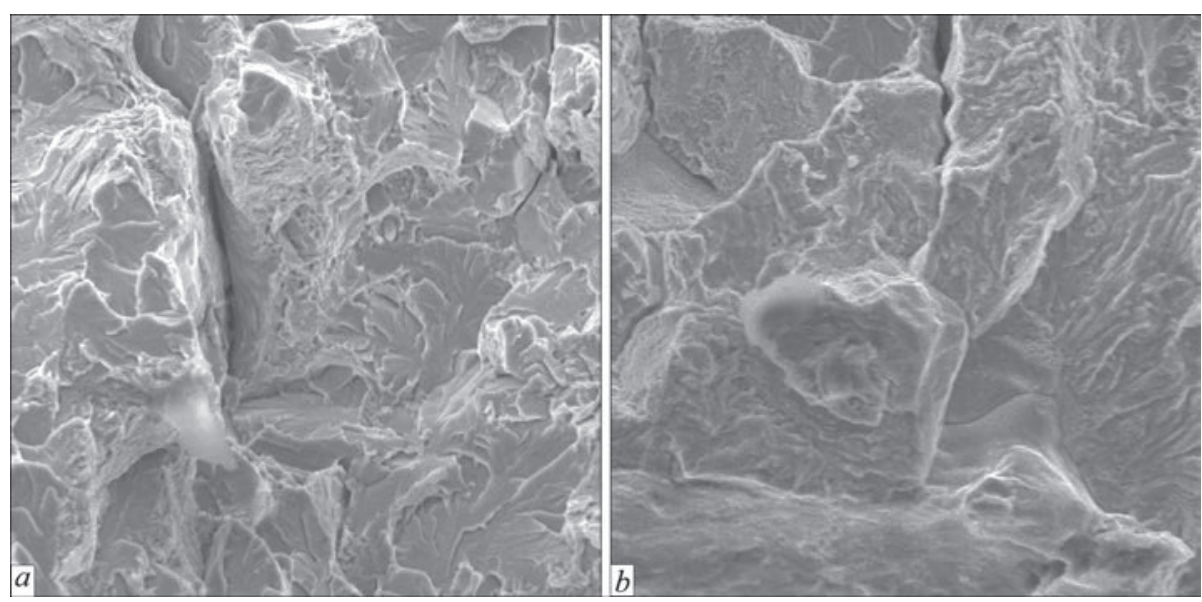

Figure 10. Fracture $(\times 1010)$ at propagation of main crack (zone II) in HAZ metal of $65 \mathrm{G}$ steel $\left(w_{6 / 5}=13.5^{\circ} \mathrm{C} / \mathrm{s}\right)$ in the presence of hydrogen: $a-[\mathrm{H}]_{\text {dif }}=0.2 ; b-0.5 \mathrm{ml} / 100 \mathrm{~g}$

In the zone of main crack development in HAZ metal of wheel steel, the fracture is brittle intragranular one, corresponding to the structure given in Figure $9, c, d$. At $w_{6 / 5}=6^{\circ} \mathrm{C} / \mathrm{s}$, secondary cracks of length up to $L_{\mathrm{s}}=40 \mu \mathrm{m}$ are observed, and at $13.5^{\circ} \mathrm{C} / \mathrm{s}$ their length does not exceed $5 \mu \mathrm{m}$. In HAZ metal of $65 \mathrm{G}$ steel the crack propagates also in the brittle mode, but fracture runs both along the boundaries (brittle intergranular), and through the grain bulk (brittle intragranular). The extent of secondary cracks in it is increased up to $60 \mu \mathrm{m}$ (Figure 9, $e$, f). In final fracture zone fracture runs in the ductile mode for all the samples.

In the presence of hydrogen, brittle intergranular fraction in the fracture increases in HAZ metal at crack propagation. Generalized results of studying the fractures are given in the Table, and Figure 10 shows the characteristic fractures of hydrogenated samples.

Analysis of the given data shows that at diffusible hydrogen saturation of HAZ metal of high-strength carbon steels, the fraction of brittle intergranular fracture is significantly increased. Particularly abrupt changes of fracture structure are characteristic for $65 \mathrm{G}$ steel. At $w_{6 / 5}=6{ }^{\circ} \mathrm{C} / \mathrm{s}$, when HAZ metal forms a bainitic-martensitic structure (70/30), hydrogen presence on the level of $0.2 \mathrm{ml} / 100 \mathrm{~g}$ leads to increase of the fraction of brittle intergranular fracture up to $50 \%$. Here, $K_{1 C}$ value decreases 3.2 times. Increase of the fraction of brittle intergranular fracture in the presence of hydrogen is characteristic also for HAZ metal of grade 2 wheel steel. However, as a result of formation of more ductile structures, brittle fracture resistance decreases by just $20 \%$. With increase of hydrogen content, the extent of secondary cracks in the fracture of samples of HAZ metal of grade 2 wheel steel increases 3 times, and in $65 \mathrm{G}$ steel - more than 3.5-6 times.

Conducted studies showed that in welding and surfacing of high-strength carbon steels, two main conditions should be satisfied, in order to ensure comparatively high brittle fracture resistance of HAZ metal. First, bainitic-martensitic structure with more than $50 \%$ volume fraction of martensite should form in the HAZ metal. And secondly, diffusible hydrogen concentration in the deposited metal should be not more than $1.5 \mathrm{ml} / 100 \mathrm{~g}$ (hydrogen saturation of HAZ metal on the level of $0.2 \mathrm{ml} / 100 \mathrm{~g}$, respectively). With increase of carbon content, diffusible hydrogen impact on HAZ metal embrittlement becomes stronger.

\section{Conclusions}

1. Brittle fracture resistance of high-strength steels with carbon content of $0.55-0.65 \%$ essentially depends on steel structural state and carbon content. Cracking resistance of steel with bainitic structure is 1.4 times higher than that of steel with pearlitic-ferritic structure. 
2. At saturation of wheel steel of grade $2(0.58 \% \mathrm{C})$ by hydrogen in the amount of $1.5 \mathrm{ml} / 100 \mathrm{~g}$ critical stress intensity factor at crack propagation decreases 1.7 times. Brittle fracture resistance of steel with $0.65 \% \mathrm{C}$ decreases almost 2.1 times at similar quantity of hydrogen.

3. During welding of joints of high-strength carbon steels a hardening structure forms in HAZ overheated zone. Phase composition of this structure depends on carbon content in the metal and its cooling rate. To achieve a relatively high resistance of joints to crack propagation, it was necessary to ensure in the HAZ metal formation of bainitic-martensitic structure, in which upper bainite is absent, and volume fraction of martensite is not greater than that of lower bainite.

4. Hydrogen, diffusing from the deposited metal, promotes an abrupt embrittlement of HAZ metal in high-strength carbon steels. To increase brittle fracture resistance of HAZ metal, it is necessary to apply welding processes, which provide $[\mathrm{H}]_{\text {dif }} \leq 1.5 \mathrm{ml} / 100 \mathrm{~g}$ in the deposited metal, or special technological methods, allowing removal of diffusible hydrogen from HAZ metal.

1. Shorshorov, M.Kh. (1965) Metals science of welding of steel and titanium alloys. Moscow: Nauka.

2. Grabin, V.F., Denisenko, A.V. (1978) Metals science of welding of low- and medium-alloy steels. Kiev: Naukova Dumka.

3. Kasatkin, O.G. (1994) Peculiarities of hydrogen embrittlement of high-strength steels in welding. Avtomatich. Svarka, 1, 3-7.
4. Ignatenko, A.V., Pokhodnya, I.K., Paltsevich, A.P. et al. (2012) Dislocation model of hydrogen-enhanced localizing of plasticity in metals with bec lattice. The Paton Welding J., 3, $15-19$.

5. Gajvoronsky, A.A. (2013) Influence of diffusible hydrogen on delayed cracking resistance of high-carbon steel welded joints. Ibid., 5, 14-20.

6. Sarzhevsky, V.A., Gajvoronsky, A.A., Gordonny, V.G. et al. (1996) Influence of technological factors on structure and properties of HAZ metal in repair-restoration surfacing of allrolled wheel flanges. Avtomatich. Svarka, 3, 22-27, 33.

7. Gajvoronsky, A.A., Poznyakov, V.D., Markashova, L.I. et al. (2012) Influence of deposited metal composition on structure and mechanical properties of reconditioned railway wheels. The Paton Welding J., 8, 16-22.

8. (1972) New methods for evaluation of resistance of metals to brittle fracture. Ed. by Yu.N. Robotnov. Moscow: Mir.

9. Shorshorov, M.Kh., Chernyshova, T.A., Krasovsky, A.I. (1972) Weldability testing of metals. Moscow: Metallurgiya.

10. GOST 25.506: Methods of mechanical tests of metals. Characterization of crack resistance (fracture toughness) in static loading.

11. Makhnenko, V.I., Korolyova, T.V., Lavrinets, I.G. (2002) Effect of microstructural transformations on redistribution of hydrogen in fusion welding of structural steels. The Paton Welding J., 2, 6-13.

12. Ostash, O.P., Andreiko, I.M., Kulyk, V.V. et al. (2009) Influence of the mode of thermal treatment and load ratio on the cyclic crack-growth resistance of wheel steels. Materials Sci., 45(2), 211-219.

13. Gajvoronsky, A.A., Zhukov, V.V., Vasiliev, V.G. et al. (2014) Structural changes in overheating zone of HAZ metal of railway wheels in arc surfacing. The Paton Welding J., 1, 13-19.

14. Gajvoronsky, A.A., Zhukov, V.V., Shishkevich, A.S. (2014) Weldability of high-strength carbon steel 65G. Svarka i Diagnostika, 5, 50-54. 